\title{
EFFECT AND EFFICIENCY OF SELECTION PROCEDURES IN TWO DURUM WHEAT POPULATIONS UNDER NEW VALLEY CONDITIONS
}

\author{
MOUBARAK, MOHAMED Y. GH.
}

Wheat Research Department, Field Crops Research Institute, ARC, Giza

(Manuscript received 29 November 2011)

\begin{abstract}
This study was conducted on the experimental farm of the New Valley Agricultural Research Station, Agricultural Research Center, Egypt, from 2008/2009 to and 2010/2011 seasons. The objective of this study was to estimate efficiency of pedigree, modified bulk and single seed descent methods in two durum wheat populations. The final evaluation of $\mathrm{F}_{5}$ generation was done during 2010/2011 season. The selected plants were sown in two experiments using randomized complete block design with four replications. Efficiency of each breeding methodology was evaluated on the basis of following parameters: mean performance, deviation between method of breeding and check, phenotypic and genotypic variances, phenotypic and genotypic coefficients of variability and broad sense heritability. Results indicated that, differences among genotypes, among selection methods and among selected families within all breeding selection methods were significant for all studied characters. Mean and actual response to selection possessed low values in pedigree method for days to heading, and in single seed descent and modified bulk methods for plant height. Whereas, mean and deviation between method of breeding and check possessed high values in pedigree and single seed descent methods for spikes per plant, and in pedigree and modified bulk methods for kernels per spike, kernel weight and grain yield per plant.

On the other hand, broad sense heritability exhibited high values in pedigree method for plant height, kernels per spike, kernel weight and grain yield per plant and in modified bulk method for spikes per plant, and in single seed descent method for days to heading, plant height, spikes per plant and kernel weight. These results refer that the three methods are effective in improving shortness, spikes per plant, kernels per spike and 100kernel weight, while, pedigree and modified bulk methods are effective in improving earliness and grain yield per plant.
\end{abstract}

\section{INTRODUCTION}

Wheat (Triticium aestivum L.) is one of the major cereal crops in Egypt, which receives the most attention of specialists in plant breeding. Plant breeders are seeking continuously for more effective and efficient selection procedure. Numerous methods have been proposed, but only a few valid comparisons have been made among there 
procedures. Also, plant breeders are continually faced by the problem of how to evaluate available breeding materials.

There were significant differences among genotypes (Moubarak, 2007), among selection methods (Pawar et. al. 1997) and among families within breeding methods (Mahdy et al., 1996). The mean and the deviation between methods of breeding and check possessed best values in pedigree and single seed descent methods for plant height and kernels per spike, in modified bulk and single seed descent methods for days to heading, spikes per plant and grain yield per plant, and in pedigree and modified bulk methods for kernel weight (Moubarak, 2007). Values of phenotypic variance were high for plant height, days to heading and kernels per spike. On the other hand, values of genotypic variance were high for days to heading, plant height, spikes per plant and kernels per spike. Meanwhile, values of phenotypic coefficient of variability were high for spikes per plant, kernels per spike, kernel weight and grain yield per plant. On the other side, values of genotypic coefficient of variability were high for spikes per plant, kernels per spike, kernel weight and grain yield per plant (Mahmoud, 2006). However, the highest genotypic and phenotypic coefficients of variation and heritability was recorded for grain yield per plant and spikes per plant (Subhashchandra, et. al. 2009). The phenotypic and genotypic variances, the phenotypic and genotypic coefficients of variability, and the broad sense heritability exhibited high values in modified bulk method for plant height, spikes per plant, kernels per spike and kernel weight, in pedigree method for days to heading, spikes per plant, kernels per spike and kernel weight; and in single seed descent method for kernel weight and grain yield per plant (Moubarak, 2007). Values of broad sense heritability were high for spikes per plant, kernels per spike, kernel weight and grain yield per plant (Chander, et. al. 1993) and for plant height, days to heading, spikes per plant, kernels per spike, kernel weight and grain yield per plant (Mahmoud, 2006). Single seed descent method proved to be most efficient and better method in selection for grain yield per plant (Pawar, et. al. 2001). Pedigree method proved to be the most efficient and the best method in selection for days to heading (Ismail, 1995), for kernels per spike (Verma, et. al. 1997) and for kernel weight (Ismail, 1995 and Verma, et. al. 1997). Meanwhile, Ismail (1995) and Fahim, et. al. (1996), found that the modified bulk method was as effective as pedigree method. The best methods of selection for spikes per plant was bulk method followed by pedigree method, for kernels per spike was modified bulk two method followed by pedigree method, for kernel weight and grain yield per plant modified bulk one method was the best followed by modified bulk two method (El-Sayed, 2006). 
Grain yield exhibited genotypic correlation with kernel weight (Mahdy et. al. 1996). Grain yield had positive and significant phenotypic and genotypic correlations with each of days to heading and spikes per plant, on the other hand, it had positive and insignificant relationship with each of kernels per spike and kernel weight for phenotypic level, but, it was significant in the genotypic level (Tammam, 2000). Kernels per spike had the highest positive correlation with grain yield per plant, followed by kernel weight. Days to heading showed negative and significant correlation with grain yield per plant (Singh and Singh, 2001). Moreover, days to heading had positive and significant correlation with plant height. Grain yield per plant had positive and significant correlations with days to heading and plant height, respectively, but these correlations were found to be negative. Kernel weight had positive and significant correlations with each of days to heading and plant height (Budak and Yildirin, 2002). Positive and significant correlations were between grain yield per plant and each of days to heading, plant height, spikes per plant and kernels per spike (Attia, 2003). Phenotypic and genotypic correlations were negative and significant between kernel weight and each of days to heading and plant height. But it was positive and significant between grain yield per plant and each of spikes per plant, kernels per spike and kernel weight (Moubarak, 2007). Successful breeding programs need enough information about breeding methods of selection. The objective of this study was to study analysis of variance and correlation of three breeding methods in two durum wheat populations by six economic characters of wheat, i. e., days to heading, plant height, spikes per plant, kernels per spike, kernel weight and grain yield per plant under the New Valley conditions.

\section{MATERIALS AND METHODS}

The present study aimed to investigate the efficiency of three breeding methods of selection used in wheat breeding program on two tetraploid durum wheat ( Triticum turgium L. Var. durum) populations.

Table 1. Pedigree and origin of the two wheat populations.

\begin{tabular}{|l|l|l|l|}
\hline Cross no. & \multicolumn{1}{|c|}{ Parental name } & \multicolumn{1}{|c|}{ Pedigree } & Origin \\
\hline 9240 & Population I & Terbol-97-4/3/Gbch-1//Stj/Mrb. & ACSAD \\
9325 & Population II & Bcrch-1/ACSAD-1129. & ACSAD \\
\hline
\end{tabular}

In pedigree method, 250 plants from each population were selected from $F_{2}$ populations and each selected plant was sown in a row as $F_{3}$ family during 2008/2009 season. Selection among and within families was practiced. Fifty families were raised 
as $\mathrm{F}_{4}$ families in $2009 / 2010$ season for each population. Ten families were selected from $\mathrm{F}_{4}$ generation for each population to be raised as $\mathrm{F}_{5}$ plants in final evaluation trial during 2010/2011 season.

In modified bulk method, grains of selected plants from each $F_{2}$ population were mixed to form population seed bulk. Mixed grains were planted during $2008 / 2009$ season as $F_{3}$ generations. Selection was practiced on the basis of the best plants per each population. Grains of selected plants were mixed to form bulk seeds, then, grains sample was taken to be raised as $F_{4}$ generations during season of 2009/2010. Similarly, ten plants per population were selected and harvested individually. Grains from each plant were kept and planted separately as $F_{5}$ plants in final evaluation trial during 2010/2011 season.

In single seed descent method, one grain was taken from 500 plants from $F_{2}$ populations and was kept individually to be planted during 2008/2009 season as $F_{3}$ generations. One grain was taken from each plant to be grown as $F_{4}$ generations during season of 2009/2010. Similarly, ten plants from each population were selected and harvested individually. Grains from each plant were kept and planted separately as $F_{5}$ plants in final evaluation trial during 2010/2011 season. Under all studied methods, each selected plant was represented by one row per plot; each row was three meters long, $20 \mathrm{~cm}$. apart and $10 \mathrm{~cm}$. within row.

Data for mean of 30 families and three checks (Sohag-3, Bani-Suif-3 and Bani-Suif-1) for each population were subjected to analysis of variance in randomized complete block design with four replications according to Snedecor and Cochran (1967). Also, ten families, for each selection method were analyzed to compute genetic parameters and variability in each selection method for each population according to formula developed by Burton (1952).

Table 2. Analysis of variance and expected mean squares according to Walker (1960).

\begin{tabular}{|c|c|c|c|c|}
\hline \multirow[t]{2}{*}{ S. O. v. } & \multirow[t]{2}{*}{ D. F. } & \multirow[t]{2}{*}{ M. S. } & \multicolumn{2}{|l|}{ E. M. S. } \\
\hline & & & Variance & Covariance \\
\hline Replications & $r-1$ & $M_{3}$ & $\sigma^{2} e+g \sigma^{2} r$ & \\
\hline Genotypes & $g-1$ & $M_{2}$ & $\sigma^{2} e+r \sigma^{2} g$ & cov.e + r cov.g \\
\hline Error & $(r-1)(g-1)$ & $M_{1}$ & & cov.e \\
\hline
\end{tabular}

Phenotypic and genotypic correlation coefficients were calculated as outlined by Johnson et. al. (1955).

\section{RESULTS AND DISCUSSIONS}

The results in Table (3) showed significant differences among genotypes, among selection methods and among selected families within all selection methods for 
days to heading, plant height, spikes per plant, kernels per spike, 100-kernel weight and grain yield per plant in two durum wheat populations. These results are in harmony with Mahdy et. al. (1996), Pawar et. al. (1997) and Moubarak (2007).

Table 3. Analysis of variance for F5 families under three breeding methods in two durum wheat populations.

\begin{tabular}{|c|c|c|c|c|c|c|c|c|}
\hline \multirow{2}{*}{ 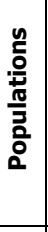 } & \multirow[b]{2}{*}{ s. o. v. } & \multirow[b]{2}{*}{ D. F. } & \multicolumn{6}{|c|}{ Mean squares } \\
\hline & & & $\begin{array}{l}\text { Days to } \\
\text { heading }\end{array}$ & $\begin{array}{l}\text { Plant } \\
\text { height }\end{array}$ & $\begin{array}{l}\text { Spikes } \\
\text { per plant }\end{array}$ & $\begin{array}{l}\text { Kernels } \\
\text { per Spike }\end{array}$ & $\begin{array}{c}100- \\
\text { kernel } \\
\text { weight }\end{array}$ & $\begin{array}{c}\text { Grain } \\
\text { yield per } \\
\text { plant } \\
\end{array}$ \\
\hline \multirow{8}{*}{ 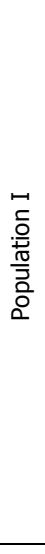 } & Replications & 3 & 0.015 & 20.626 & 0.688 & 11.851 & 0.005 & 3.614 \\
\hline & $\begin{array}{c}\text { Among } \\
\text { genotypes }\end{array}$ & 32 & $41.819^{*}$ & $995.309^{*}$ & $13.223^{*}$ & $82.757^{*}$ & $1.068^{*}$ & $166.119^{*}$ \\
\hline & Among methods & 3 & $30.449^{*}$ & $1767.530^{*}$ & $22.891^{*}$ & $177.738^{*}$ & $0.423^{*}$ & $715.797^{*}$ \\
\hline & Within PM & 9 & $52.654^{*}$ & $1383.888^{*}$ & $9.174^{*}$ & $64.664^{*}$ & $0.909^{*}$ & $162.477^{*}$ \\
\hline & Within MBM & 9 & $7.230^{*}$ & $896.122^{*}$ & $12.970^{*}$ & $83.259^{*}$ & $0.878^{*}$ & $117.518^{*}$ \\
\hline & Within SSDM & 9 & $67.370^{*}$ & $513.433^{*}$ & $16.070^{*}$ & $64.226^{*}$ & $1.775^{*}$ & $48.643^{*}$ \\
\hline & Within checks & 2 & $50.788^{*}$ & $703.155^{*}$ & $5.269^{*}$ & $102.834^{*}$ & $0.430^{*}$ & $105.337^{*}$ \\
\hline & Error & 96 & 1.991 & 5.759 & 0.490 & 5.221 & 0.039 & 2.410 \\
\hline \multirow{8}{*}{ 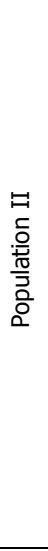 } & Replications & 3 & 1.202 & 15.766 & 0.747 & 5.730 & 0.012 & 4.129 \\
\hline & $\begin{array}{c}\text { Among } \\
\text { genotypes }\end{array}$ & 32 & $71.028^{*}$ & $264.385^{*}$ & $10.686^{*}$ & $122.885^{*}$ & $0.820^{*}$ & $98.382^{*}$ \\
\hline & Among methods & 3 & $130.253^{*}$ & $601.926^{*}$ & $47.957^{*}$ & $87.988^{*}$ & $0.522^{*}$ & $309.817^{*}$ \\
\hline & Within PM & 9 & $77.522^{*}$ & $158.345^{*}$ & $4.968^{*}$ & $136.819^{*}$ & $1.236^{*}$ & $110.245^{*}$ \\
\hline & Within MBM & 9 & $80.316^{*}$ & $127.705^{*}$ & $6.147^{*}$ & $119.633^{*}$ & $1.178^{*}$ & $85.483^{*}$ \\
\hline & Within SSDM & 9 & $40.002^{*}$ & $297.087^{*}$ & $9.723^{*}$ & $128.291^{*}$ & $0.233^{*}$ & $27.394^{*}$ \\
\hline & Within checks & 2 & $50.788^{*}$ & $703.155^{*}$ & $5.269^{*}$ & $102.834^{*}$ & $0.430^{*}$ & $105.337^{*}$ \\
\hline & Error & 96 & 1.300 & 5.615 & 0.229 & 11.463 & 0.044 & 3.227 \\
\hline
\end{tabular}

* Significant at 0.05 level.

Data of days to heading are presented in Table (4), indented that pedigree method recorded less values of mean and deviation between method of breeding and check in two populations. Meanwhile, single seed descent and modified bulk methods exhibited the highest values of phenotypic and genotypic variances, phenotypic and genotypic coefficients of variability in population I and II, respectively. Furthermore, single seed descent method possessed the highest values of broad sense heritability compared to the other methods in two populations. These results clear that pedigree, modified bulk and single seed descent methods are more effective in improving 
earliness. Similar results were found by Ismail (1995), Fahim et. al. (1996), Mahmoud (2006) and Moubarak (2007).

Results of plant height as shown in Table (4) revealed that, single seed descent and modified bulk methods had less values of mean and deviation between method of breeding and check in population I and II, respectively. Moreover, pedigree and single seed descent methods possessed the highest values of phenotypic and genotypic variances, phenotypic and genotypic coefficients of variability and broad sense heritability in population I, and II, respectively. These results refer that pedigree, modified bulk and single seed descent methods are more effective in improving shortness. These results are in harmony with Mahmoud (2006) and Moubarak (2007).

Data of spikes per plant are presented in Table (4), indented that pedigree and single seed descent methods recorded the highest values of mean and deviation between methods of breeding and checks in population I, and II, respectively. Moreover, single seed descent method possessed the highest values of phenotypic and genotypic variances and phenotypic and genotypic coefficients of variability in the two populations. However, modified bulk and single seed descent methods exhibited the highest values of broad sense heritability in population I and II, respectively. These results refer that pedigree, modified bulk and single seed descent methods are more effective in improving spikes per plant. These results are in harmony with Chander, et al., (1993), El-Sayed (2006), Mahmoud (2006), Moubarak (2007) and Subhashchandra, et al., (2009).

Values of kernels per spike illustrated in Table (4), revealed that pedigree and modified bulk methods had highest values for mean and deviation between method of breeding and check in population I and II, respectively. In most cases, modified bulk method possessed the highest values of phenotypic and genotypic variances and phenotypic and genotypic coefficients of variability in population I, while single seed descent method had the highest values of phenotypic variance and phenotypic coefficient of variability in population II, and, pedigree method gave the highest values of genotypic variance and genotypic coefficient of variability in population II. Furthermore, pedigree method possessed the highest values of broad sense heritability compared to the other methods in two populations. These results refer that pedigree, modified bulk and single seed descent methods are more effective in improving kernels per spike. These results are in harmony with El-Sayed (2006), Mahmoud (2006) and Moubarak (2007). 
Results of kernel weight are shown in (Table 4). Pedigree and modified bulk methods had the highest values of mean and deviation between method of breeding and check in population I and II, respectively. Meanwhile, single seed descent and pedigree methods recorded the highest values of phenotypic and genotypic variances, phenotypic and genotypic coefficients of variability and broad sense heritability in population I and II, respectively. These results reveal that pedigree, modified bulk and single seed descent methods are effective in improving kernel weight. These results are in harmony with Ismail (1995), Fahim, et. al. (1996), El-Sayed (2006) and Mahmoud (2006).

Data of grain yield per plant are presented in Table (4). Results revealed that, applying pedigree and modified bulk selection methods gave the highest values for mean and deviation between method of breeding and check in population I and II, respectively. Meanwhile, pedigree method had the highest values of phenotypic and genotypic variances and broad sense heritability in two populations. However, modified bulk and pedigree methods possessed the highest values of phenotypic and genotypic coefficients of variability in population I and II, respectively. These results indicate that pedigree and modified bulk methods are more effective in improving grain yield. Similar results were found by Chander et. al. (1993), Pawar et. al. (2001), El-Sayed (2006), Mahmoud (2006), Moubarak (2007) and Subhashchandra et. al. (2009).

Results of correlation under pedigree method in population I are presented in Table (5). Phenotypic and genotypic correlations were significant between plant height and each of spikes per plant, kernels per spike, 100-kernel weight and grain yield per plant. Phenotypic and genotypic correlations between spikes per plant and grain yield per plant were positive and significant. These results indicated that selection for spikes per plant may increase grain yield per plant in these materials. In addition, genotypic correlation between spikes per plant and kernels per spike was positive and significant. Phenotypic and genotypic correlations were positive and significant between kernels per spike and each of kernel weight and grain yield per plant. Hence, for improving grain yield per plant in wheat, selection should be largely depending upon kernels per spike. These results are in line with those reported by Tammam (2000), Singh and Singh (2001), Budak and Yildirin (2002), Attia (2003) and Moubarak (2007). 
Table 4. Mean performance, deviation and genetic parameters of the F5 families for three breeding methods in two populations.

\begin{tabular}{|c|c|c|c|c|c|c|c|}
\hline \multirow[t]{2}{*}{ Characters } & \multirow[t]{2}{*}{ Parameters } & \multicolumn{3}{|c|}{ Population I } & \multicolumn{3}{|c|}{ Population II } \\
\hline & & PM & MBM & SSDM & PM & MBM & SSDM \\
\hline \multirow{9}{*}{ 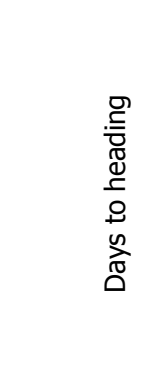 } & Mean & 79.28 & 80.22 & 80.98 & 87.49 & 88.16 & 87.82 \\
\hline & $\mathrm{D} \mathrm{ch}_{1}$ & 0.47 & 1.40 & 2.17 & 8.68 & 9.35 & 9.01 \\
\hline & $\mathrm{D} \mathrm{ch}_{2}$ & -6.52 & -5.590 & -4.82 & 1.69 & 2.36 & 2.02 \\
\hline & $\mathrm{D} \mathrm{ch}_{3}$ & -1.82 & -0.89 & -0.12 & 6.39 & 7.05 & 6.72 \\
\hline & $\sigma^{2} p$ & 14.79 & 2.91 & 18.83 & 20.40 & 21.50 & 10.49 \\
\hline & $\sigma^{2} g$ & 12.62 & 1.44 & 16.18 & 19.04 & 19.61 & 9.836 \\
\hline & P.C.V. \% & 4.85 & 2.13 & 5.36 & 5.16 & 5.26 & 3.69 \\
\hline & G.C.V. $\%$ & 4.48 & 1.50 & 4.97 & 4.99 & 5.02 & 3.57 \\
\hline & $\mathrm{h}^{2}$ & 85.34 & 49.49 & 85.94 & 93.32 & 91.21 & 93.74 \\
\hline \multirow{9}{*}{ 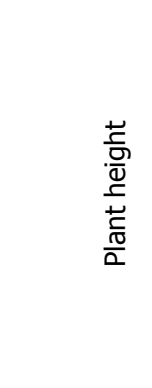 } & Mean & 106.06 & 114.55 & 100.87 & 109.44 & 105.57 & 105.90 \\
\hline & $\mathrm{D} \mathrm{ch}_{1}$ & -4.48 & 4.02 & -9.66 & -1.09 & -4.96 & -4.63 \\
\hline & $\mathrm{D} \mathrm{ch}_{2}$ & 20.57 & 29.07 & 15.38 & 23.96 & 20.08 & 20.42 \\
\hline & $\mathrm{D} \mathrm{ch}_{3}$ & 15.59 & 24.09 & 10.41 & 18.98 & 15.10 & 15.44 \\
\hline & $\sigma^{2} p$ & 349.355 & 229.30 & 134.25 & 43.80 & 36.98 & 78.55 \\
\hline & $\sigma^{2} \mathrm{~g}$ & 344.845 & 222.28 & 126.39 & 38.18 & 30.241 & 72.85 \\
\hline & P.C.V. \% & 17.624 & 13.22 & 11.49 & 6.05 & 5.761 & 8.37 \\
\hline & G.C.V. \% & 17.509 & 13.02 & 11.15 & 5.65 & 5.209 & 8.06 \\
\hline & $h^{2}$ & 98.709 & 96.94 & 94.15 & 87.184 & 81.768 & 92.74 \\
\hline \multirow{9}{*}{ 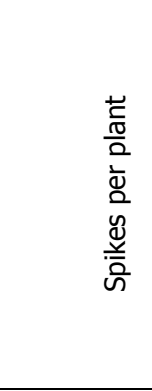 } & Mean & 9.645 & 8.51 & 9.29 & 7.70 & 7.214 & 7.76 \\
\hline & $\mathrm{D} \mathrm{ch}{ }_{1}$ & -1.300 & -2.44 & -1.65 & -3.24 & -3.73 & -3.18 \\
\hline & $\mathrm{D} \mathrm{ch}_{2}$ & -0.390 & -1.53 & -0.74 & -2.33 & -2.82 & -2.27 \\
\hline & $\mathrm{D} \mathrm{ch}_{3}$ & -2.670 & -3.81 & -3.02 & -4.61 & -5.10 & -4.55 \\
\hline & $\sigma^{2} p$ & 2.751 & 3.52 & 4.44 & 1.40 & 1.74 & 2.59 \\
\hline & $\sigma^{2} \mathrm{~g}$ & 2.141 & 3.15 & 3.88 & 1.19 & 1.47 & 2.38 \\
\hline & P.C.V. \% & 17.12 & 22.04 & 22.68 & 15.38 & 18.31 & 20.75 \\
\hline & G.C.V. \% & 15.17 & 20.87 & 21.18 & 14.16 & 16.79 & 19.86 \\
\hline & $\mathrm{h}^{2}$ & 77.83 & 89.67 & 87.24 & 84.742 & 84.17 & 91.60 \\
\hline \multirow{9}{*}{ 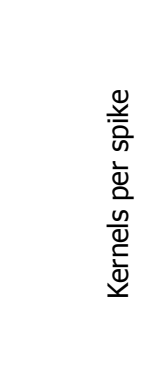 } & Mean & 49.77 & 45.36 & 45.85 & 53.961 & 54.21 & 52.30 \\
\hline & $\mathrm{D} \mathrm{ch}{ }_{1}$ & -0.41 & -4.82 & -4.32 & 3.79 & 4.03 & 2.13 \\
\hline & $\mathrm{D} \mathrm{ch}_{2}$ & 5.711 & 1.30 & 1.80 & 9.91 & 10.152 & 8.25 \\
\hline & $\mathrm{D} \mathrm{ch}_{3}$ & -4.35 & -8.76 & -8.27 & -0.16 & 0.09 & -1.82 \\
\hline & $\sigma^{2} p$ & 17.65 & 26.51 & 18.7 & 36.72 & 34.18 & 49.52 \\
\hline & $\sigma^{2} \mathrm{~g}$ & 15.67 & 18.92 & 15.18 & 33.37 & 28.49 & 26.26 \\
\hline & P.C.V. \% & 8.44 & 11.35 & 9.43 & 11.23 & 10.79 & 13.46 \\
\hline & G.C.V. $\%$ & 7.95 & 9.60 & 8.50 & 10.71 & 9.85 & 9.80 \\
\hline & $\mathrm{h}^{2}$ & 88.81 & 71.38 & 81.17 & 90.87 & 83.35 & 53.02 \\
\hline
\end{tabular}


Cont. Table 4.

\begin{tabular}{|c|c|c|c|c|c|c|c|}
\hline \multirow[t]{2}{*}{ Characters } & \multirow[t]{2}{*}{ Parameters } & \multicolumn{3}{|c|}{ Population I } & \multicolumn{3}{|c|}{ Population II } \\
\hline & & PM & MBM & SSDM & PM & MBM & SSDM \\
\hline \multirow{9}{*}{ 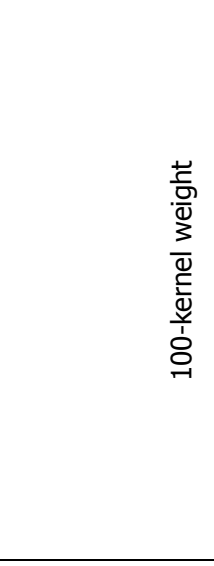 } & Mean & 5.54 & 5.48 & 5.41 & 5.41 & 5.49 & 5.38 \\
\hline & $\mathrm{DCh}_{1}$ & 0.03 & -0.04 & -0.11 & -0.11 & -0.02 & -0.14 \\
\hline & $\mathrm{DCh}_{2}$ & -0.11 & -0.17 & -0.24 & -0.24 & -0.16 & -0.28 \\
\hline & $\mathrm{Dch}_{3}$ & -0.60 & -0.66 & -0.73 & -0.73 & -0.65 & -0.76 \\
\hline & $\sigma^{2} p$ & 0.25 & 0.25 & 0.47 & 0.34 & 0.34 & 0.08 \\
\hline & $\sigma^{2} g$ & 0.22 & 0.21 & 0.43 & 0.30 & 0.28 & 0.05 \\
\hline & P.C.V. \% & 9.03 & 9.15 & 12.70 & 10.83 & 10.56 & 5.15 \\
\hline & G.C.V. \% & 8.46 & 8.34 & 12.17 & 10.08 & 9.64 & 4.24 \\
\hline & $h^{2}$ & 87.81 & 83.05 & 91.83 & 86.70 & 83.48 & 67.76 \\
\hline \multirow{9}{*}{ 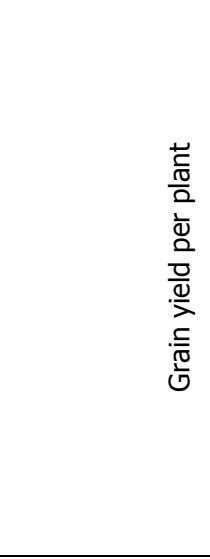 } & Mean & 23.78 & 19.46 & 16.85 & 21.04 & 21.88 & 20.86 \\
\hline & $\mathrm{DCh}_{1}$ & -8.66 & -12.98 & -15.59 & -11.40 & -10.56 & -11.58 \\
\hline & $\mathrm{DCh}_{2}$ & -0.75 & -5.07 & -7.68 & -3.49 & -2.65 & -3.67 \\
\hline & $\mathrm{DCh}_{3}$ & -10.37 & -14.69 & -17.30 & -13.11 & -12.27 & -13.29 \\
\hline & $\sigma^{2} p$ & 42.28 & 31.20 & 13.52 & 28.99 & 24.74 & 8.87 \\
\hline & $\sigma^{2} \mathrm{~g}$ & 40.06 & 28.77 & 11.71 & 27.08 & 20.25 & 6.17 \\
\hline & P.C.V. \% & 27.35 & 28.71 & 21.82 & 25.59 & 22.74 & 14.28 \\
\hline & G.C.V. \% & 26.62 & 27.57 & 20.31 & 24.74 & 20.57 & 11.91 \\
\hline & $h^{2}$ & 94.75 & 92.22 & 86.62 & 93.42 & 81.83 & 69.58 \\
\hline
\end{tabular}

PM: pedigree method.

MBM: modified bulk method.

SSDM: single seed descent methods.

Data of correlation under modified bulk method in population I presented in Table (6). Genotypic correlation between days to heading and plant height was negative and significant. Moreover, phenotypic and genotypic correlations between plant height and grain yield per plant were negative and significant. While, phenotypic and genotypic correlations between spikes per plant and each of kernels per spike and grain yield per plant were positive and significant. Furthermore, phenotypic and genotypic correlations between kernels per spike and grain yield per plant were positive and significant. These results indicated that selection for kernels per spike may increase grain yield per plant in these materials. These results are agreement with those reported by Tammam (2000), Budak and Yildirin (2002), Attia (2003) and Moubarak (2007). 
Values of correlation under single seed descent method in population I are shown in Table (7). Days to heading exhibited negative and significant phenotypic and genotypic correlations with kernels per spike and kernel weight. While phenotypic and genotypic correlations between spikes per plant and kernels per spike were significant. Moreover, significant and positive phenotypic and genotypic correlations were recorded between kernel weight and grain yield per plant. Hence, for improving grain yield per plant in wheat, selection should be largely depending upon on kernel weight. These results are in harmony with Mahdy et. al. (1996), Tammam (2000) and Moubarak (2007).

Results of correlation under pedigree method in population II are illustrated in Table (5). Values of phenotypic and genotypic correlations revealed that days to heading was negative and significant correlated with kernels per spike, 100-kernel weight and grain yield per plant. These results indicated that selection for days to heading may increase grain yield per plant. Whereas, negative and significant phenotypic and genotypic correlations were found between plant height and each of kernels per spike and kernel weight. While, positive and significant phenotypic and genotypic correlations were found between spikes per plant and grain yield per plant. Moreover, phenotypic and genotypic correlations were positive and significant between 100-kernel weight and grain yield per plant. Hence, for improving grain yield per plant in wheat, selection should be largely depending upon kernel weight. Similar results are found by Mahdy et. al. (1996), Tammam (2000), Singh and Singh (2001), Budak and Yildirin (2002), Attia (2003) and Moubarak (2007).

Correlations under modified bulk method in population II are presented in Table (6). Phenotypic and genotypic correlations between days to heading and kernels per spike were negative and significant. Furthermore, phenotypic and genotypic correlations between plant height and each of spikes per plant, kernels per plant and 100-kernel weight were negative and significant. While, phenotypic and genotypic correlations between spikes per plant and each of 100-kernel weight and grain yield per plant were positive and significant. Moreover, phenotypic and genotypic correlations between kernels per spike and each of 100-kernel weight and grain yield per plant were positive and significant. While, phenotypic and genotypic correlations between 100-kernel weight and grain yield per plant were positive and significant. Hence, for improving grain yield per plant in wheat, selection should be largely depending upon kernels per spike and kernel weight. These results are in harmony with Mahdy et. al. (1996) and Moubarak (2007).

Values of correlation under single seed descent method in population II are recorded in Table (7). Negative and significant genotypic correlation was recorded 
between days to heading and kernel weight. Phenotypic and genotypic correlations between spikes per plant and grain yield per plant were positive and significant. Genotypic correlation between kernels per spike and kernel weight was positive and significant. These results are in line with those reported by Tammam (2000), Singh and Singh (2001), Budak and Yildirin (2002), Attia (2003) and Moubarak (2007).

Table 5. Phenotypic (rp) and genotypic ( $\mathrm{rg}$ ) correlations estimated from the $\mathrm{F} 5$ families of pedigree method in population I (above diagonal), and in population II (below diagonal).

\begin{tabular}{|c|c|c|c|c|c|c|c|}
\hline Traits & & $\mathrm{DH}$ & $\mathrm{PH}$ & $S / P$ & $\mathrm{~K} / \mathrm{S}$ & $100-K W$ & $\mathrm{GY} / \mathrm{P}$ \\
\hline Days to heading $(\mathrm{DH})$ & $\begin{array}{l}\mathrm{rp} \\
\mathrm{rg}\end{array}$ & -- & $\begin{array}{l}-0.069 \\
-0.068 \\
\end{array}$ & $\begin{array}{l}0.114 \\
0.164 \\
\end{array}$ & $\begin{array}{l}0.078 \\
0.127 \\
\end{array}$ & $\begin{array}{l}-0.206 \\
-0.214 \\
\end{array}$ & $\begin{array}{l}-0.008 \\
0.002 \\
\end{array}$ \\
\hline Plant height (PH) & $\begin{array}{l}\mathrm{rp} \\
\mathrm{rg}\end{array}$ & $\begin{array}{l}0.281 \\
0.308 \\
\end{array}$ & -- & $\begin{array}{l}0.354^{*} \\
0.396^{*} \\
\end{array}$ & $\begin{array}{l}0.416^{*} \\
0.435^{*} \\
\end{array}$ & $\begin{array}{l}0.389^{*} \\
0.411^{*} \\
\end{array}$ & $\begin{array}{l}0.429^{*} \\
0.448^{*} \\
\end{array}$ \\
\hline Spikes/plant (S/P) & $\begin{array}{l}\mathrm{rp} \\
\mathrm{rg}\end{array}$ & $\begin{array}{l}-0.285 \\
-0.290 \\
\end{array}$ & $\begin{array}{l}-0.002 \\
0.002 \\
\end{array}$ & -- & $\begin{array}{l}0.281 \\
0.324^{*}\end{array}$ & $\begin{array}{l}-0.093 \\
-0.118 \\
\end{array}$ & $\begin{array}{l}0.731^{*} \\
0.883^{*}\end{array}$ \\
\hline Kernels/spike (K/S) & $\begin{array}{l}\mathrm{rp} \\
\mathrm{rg}\end{array}$ & $\begin{array}{l}-0.682^{*} \\
-0.765^{*} \\
\end{array}$ & $\begin{array}{l}-0.362^{*} \\
-0.395^{*} \\
\end{array}$ & $\begin{array}{l}0.199 \\
0.247 \\
\end{array}$ & -- & $\begin{array}{l}0.668^{*} \\
0.727^{*}\end{array}$ & $\begin{array}{l}0.594^{*} \\
0.632^{*}\end{array}$ \\
\hline $\begin{array}{l}\text { 100-kernel weight } \\
(100-\mathrm{KW})\end{array}$ & $\begin{array}{l}\mathrm{rp} \\
\mathrm{rg}\end{array}$ & $\begin{array}{l}-0.436^{*} \\
-0.440^{*}\end{array}$ & $\begin{array}{l}-0.355^{*} \\
-0.407^{*}\end{array}$ & $\begin{array}{l}-0.142 \\
-0.183 \\
\end{array}$ & $\begin{array}{l}0.133 \\
0.143\end{array}$ & -- & $\begin{array}{l}0.172 \\
0.179 \\
\end{array}$ \\
\hline $\begin{array}{l}\text { Grain yield/plant } \\
(\mathrm{GY} / \mathrm{P})\end{array}$ & $\begin{array}{l}\mathrm{rp} \\
\mathrm{rg}\end{array}$ & $\begin{array}{l}-0.378^{*} \\
-0.387^{*} \\
\end{array}$ & $\begin{array}{l}-0.235 \\
-0.257 \\
\end{array}$ & $\begin{array}{l}0.749^{*} \\
0.818^{*}\end{array}$ & $\begin{array}{l}0.194 \\
0.209 \\
\end{array}$ & $\begin{array}{l}0.410^{*} \\
0.425^{*} \\
\end{array}$ & -- \\
\hline
\end{tabular}

${ }^{*}$ Significant at 0.05 level.

Table 6. Phenotypic (rp) and genotypic ( $\mathrm{rg}$ ) correlations estimated from the F5 families of modified bulk method in population I (above diagonal), and in population II (below diagonal).

\begin{tabular}{|l|l|l|l|l|l|l|l|}
\hline Traits & & $\mathrm{DH}$ & $\mathrm{PH}$ & $\mathrm{S} / \mathrm{P}$ & $\mathrm{K} / \mathrm{S}$ & $100-\mathrm{KW}$ & $\mathrm{GY} / \mathrm{P}$ \\
\hline Days to heading (DH) & $\mathrm{rp}$ & -- & -0.281 & $0.574^{*}$ & 0.310 & -0.042 & $0.597^{*}$ \\
& $\mathrm{rg}$ & -- & $-0.386^{*}$ & $0.853^{*}$ & $0.651^{*}$ & -0.127 & $0.879^{*}$ \\
\hline Plant height (PH) & $\mathrm{rp}$ & $0.350^{*}$ & -- & -0.216 & -0.029 & -0.247 & $-0.510^{*}$ \\
& $\mathrm{rg}$ & $0.391^{*}$ & -- & -0.233 & -0.027 & -0.287 & $-0.550^{*}$ \\
\hline Spikes/plant (S/P) & $\mathrm{rp}$ & 0.315 & $-0.458^{*}$ & -- & $0.422^{*}$ & -0.241 & $0.730^{*}$ \\
& $\mathrm{rg}$ & $0.360^{*}$ & $-0.540^{*}$ & -- & $0.578^{*}$ & -0.238 & $0.818^{*}$ \\
\hline Kernels/spike (K/S) & $\mathrm{rp}$ & $-0.495^{*}$ & $-0.568^{*}$ & 0.249 & -- & -0.265 & $0.565^{*}$ \\
& $\mathrm{rg}$ & $-0.535^{*}$ & $-0.697^{*}$ & 0.280 & -- & $-0.404^{*}$ & $0.686^{*}$ \\
\hline $100-$-kernel weight & $\mathrm{rp}$ & -0.101 & $-0.342^{*}$ & $0.457^{*}$ & $0.492^{*}$ & -- & 0.112 \\
$(100-\mathrm{KW})$ & $\mathrm{rg}$ & -0.079 & $-0.422^{*}$ & $0.532^{*}$ & $0.522^{*}$ & -- & 0.121 \\
\hline Grain yield/plant & $\mathrm{rp}$ & -0.111 & -0.164 & $0.521^{*}$ & $0.481^{*}$ & $0.454^{*}$ & - \\
(GY/P) & $\mathrm{rg}$ & -0.110 & -0.227 & $0.609^{*}$ & $0.550^{*}$ & $0.554^{*}$ & - \\
\hline
\end{tabular}

* Significant at 0.05 level. 
Table 7. Phenotypic (rp) and genotypic ( $\mathrm{rg}$ ) correlations estimated from the F5 families of single seed descent method in population I (above diagonal), and in population II (below diagonal).

\begin{tabular}{|l|l|l|l|l|l|l|l|}
\hline Traits & & $\mathrm{DH}$ & $\mathrm{PH}$ & $\mathrm{S} / \mathrm{P}$ & $\mathrm{K} / \mathrm{S}$ & $100-\mathrm{KW}$ & $\mathrm{GY} / \mathrm{P}$ \\
\hline Days to heading (DH) & $\mathrm{rp}$ & -- & -0.177 & $0.475^{*}$ & $-0.351^{*}$ & $-0.494^{*}$ & -0.158 \\
& $\mathrm{rg}$ & -- & -0.158 & $0.570^{*}$ & $-0.365^{*}$ & $-0.539^{*}$ & -0.212 \\
\hline Plant height (PH) & $\mathrm{rp}$ & -0.029 & -- & $0.421^{*}$ & 0.010 & 0.283 & -0.172 \\
& $\mathrm{rg}$ & -0.013 & -- & $0.471^{*}$ & -0.029 & 0.305 & -0.189 \\
\hline Spikes/plant (S/P) & $\mathrm{rp}$ & -0.082 & 0.266 & -- & $-0.384^{*}$ & -0.068 & -0.061 \\
& $\mathrm{rg}$ & -0.089 & 0.274 & -- & $-0.458^{*}$ & -0.092 & -0.064 \\
\hline Kernels/spike (K/S) & $\mathrm{rp}$ & 0.013 & -0.260 & $-0.366^{*}$ & -- & 0.239 & 0.035 \\
& $\mathrm{rg}$ & -0.077 & -0.302 & $-0.507^{*}$ & -- & 0.231 & 0.063 \\
\hline 100-kernel weight & $\mathrm{rp}$ & -0.262 & 0.010 & $-0.484^{*}$ & 0.300 & -- & $0.630^{*}$ \\
(100-KW) & $\mathrm{rg}$ & $-0.365^{*}$ & 0.042 & $-0.611^{*}$ & $0.450^{*}$ & -- & $0.717^{*}$ \\
\hline \multirow{2}{*}{ Grain yield/plant (GY/P) } & $\mathrm{rp}$ & 0.017 & -0.019 & $0.470^{*}$ & -0.146 & $-0.500^{*}$ & -- \\
& $\mathrm{rg}$ & 0.050 & -0.017 & $0.630^{*}$ & $-0.333^{*}$ & $-0.668^{*}$ & - \\
\hline
\end{tabular}

${ }^{*}$ Significant at 0.05 level.

\section{REFERENCES}

1. Attia, I.A. 2003. Selection for Drought Tolerance in Wheat. Ph.D. Thesis, Agron. Dept., Fac. Agric., El-Minia Univ. Egypt.

2. Budak, N., and M.B. Yildirin. 2002. Heritability, correlation and genetic gains obtained in the populations of EGE 88 and KUNDURU durum wheats irradiated with gamma rays. Cereal Res. Commun. 30:47-53.

3. Burton, G.W. 1952. Quantitative Inheritance in Grasses. $6^{\text {th }}$ Internat. Grassland Cong. Proc. 1:227-283.

4. Chander, S., R.B. Srivastava, and M.D. Yunus. 1993. Impact of intermating on population mean and genetic advance in wheat (Triticum aestivum L. em Thell). Cereal Res., Commun. 21:201-206.

5. El-Sayed, E.A.M. 2006. Effect of four selection methods in some bread wheat crosses. J. Agric. Sci. Mansoura Univ. 31:1221-1230.

6. Fahim, M.M.P., D.S. Dhanaoala, and M.J. Lawrence. 1996. A comparison of the efficiency of four breeding methods. International Rice Res. Notes. 21:20-21.

7. Ismail, A.A. 1995. Pedigree selection for grain yield, grain weight and earliness in two segregating populations of spring wheat. Assiut J. Agric. Sci. 26:59-72.

8. Johnson, W.H., H.F. Robinson, and R.E. Comstock. 1955. Estimates of genetic and environmental variability in soybeans. Agron. J. 47:314-319. 
9. Mahdy, E.E., A.A. Ismail, and K.A. Kheiralla. 1996. The relative merits of selection index and pedigree selection in improving grain yield of spring wheat. Assiut J. Agric.Sci. 27:17-33.

10. Mahmoud, M.Sh.M. 2006. Breeding for Drought Tolerance in Bread Wheat under New Land Conditions in Upper Egypt. Ph.D. Thesis, Agron. Dep., Fac. Agric., Minia Univ. Egypt.

11. Moubarak, M.Y.Gh. 2007. Efficiency of Some Breeding Methodologies on Some Bread Wheat Populations under New Valley Conditions. Ph.D. Thesis, Agron. Dep., Fac. Agric. Minia Univ., Egypt.

12. Pawar, I.S., A.S. Redhu, S. Iqbal, and M. Yunus. 2001. Effectiveness of selection procedures in wheat. Haryana Agric. Univ. J. Res. 31:119-121.

13. Pawar, I.S., M. Yunus, S.S. Karwasra, and S. Prabalee. 1997. Use of single spike selection procedure in wheat improvement. Haryana Agric. Univ. J. Res. 27:167169.

14. Singh, S.B. and T.B. Singh. 2001. Correlation and path analysis in common wheat (Triticum aestivum L.) under light texture soil. Res. on Crops. 2:99-101.

15. Snedecor, G.W. and W.G. Cochran. 1967. Statistical Methods $6^{\text {th }}$ Ed., Iowa State. Univ. Press, Ames, Iowa, U.S.A.

16. Subhashchandra, B., H.C. Lohithaswa, S.A. Desai, R.R. Hanchinal, I.K. Kalappanavar, K.K. Math, and P.M. Salimath. 2009. Assessment of genetic variability and relationship between genetic diversity and transgressive segregation in tetraploid wheat. Karnataka J. Agric. Sci. 22:36-38.

17. Tammam, A.M. 2000. Phenotypic, genotypic correlations and path coefficient analysis in some bread wheat crosses. Assiut J. Agric. Sci. 31:73-85.

18. Verma, S.R., M. Yunus, S.K. Sethi, H.J. Braun, F. Altay, W.E. Kronstad, S.P.S. Beniwal, and A. McNab. 1997. Breeding for yield and quality in durum wheat. Developments in Plant Breeding., 6:61-64.

19. Walker, T.T. 1960. The use of a selection index technique in the analysis of progeny row data. Emp. Cott. Rev. 37:81-107. 


\section{تقدير أفضل طرق التربية في عشيرتين من قمح الديورم تحت ظروف الوادي الجديد}

\section{محمد يوسف غنيم مبارك}

$$
\text { قسم بحوث القهح - معهد بحوث المحاصيل الحقلية - مركز البحوث الزراعية. }
$$

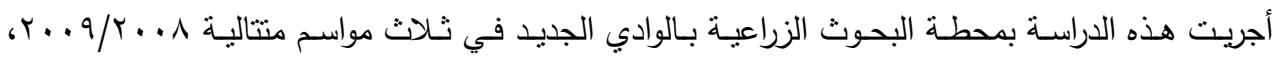

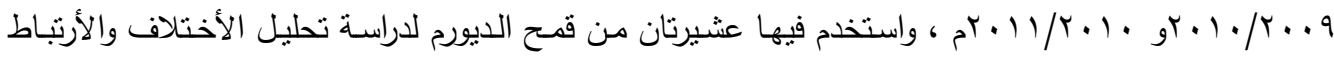
ولتقدير كفاءة ثلاثة طرق تربية هي طريقة تسجيل النسب ، طريقة التجميع المحورة وطريقة الانحدار من حبة التبة

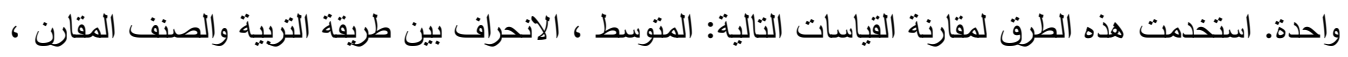

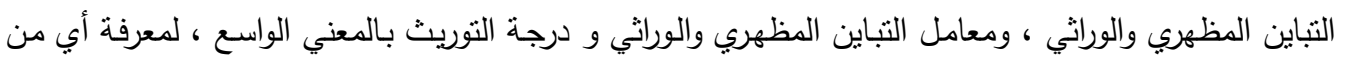
طرق التربية الثلاثة هي الأفضل. وكان التصميم المستخدم تصميم القطاعات الكاملة العشوائية في أربع مكررات

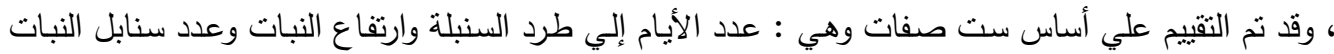
وعدد حبوب السنبلة ووزن الحبوب ومحصول النبات من الحبوب. دلت النتائج علي وجود اختلافات معنوية بين التراكيب الوراثية وطرق التربية والعائلات داخل كل طريقة من طرق التربية لجميع الصفات المدروسة.

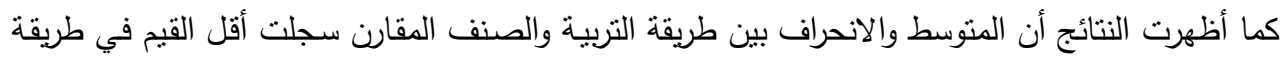
تسجيل النسب لصفة عدد الأيام إلي طرد السنابل ، وفي طريقتي الانحدار من حبة واحدة والتجميع المحورة لصفة ارتقاع النبات. بينما سجل المتوسط والانحراف بين طريقة التربية والصنف المقارن أعلي القيم في طريقتي تسجيل

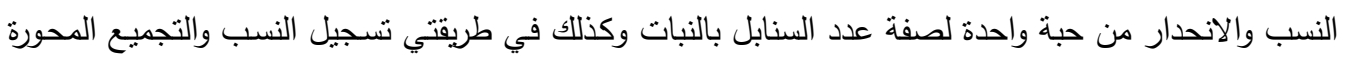
لصفات عدد الحبوب بالسنبلة ، ووزن الحبوب ومحصول الحبوب للنبات.

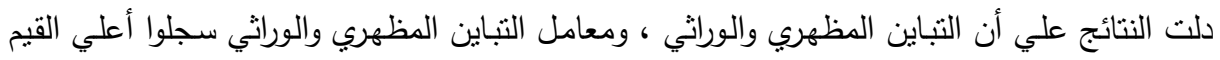

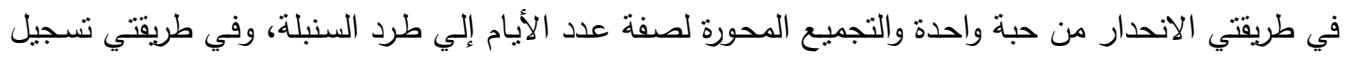
النسب والانحدار من حبة واحدة لصفة ارتفاع النبات ، وكذللك في طريقتي الانحدار من حبة واحدة وتسجيل

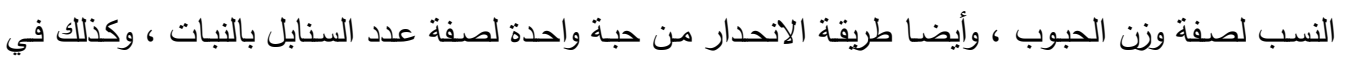

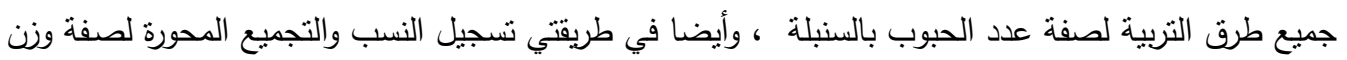

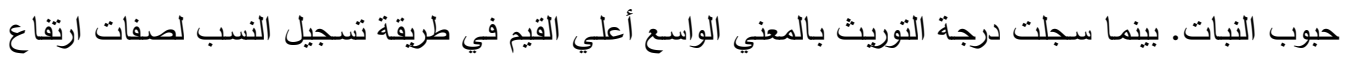
النبات وعدد الحبوب بالسنبلة ووزن الحبوب ومحصول حبوب النبات, وفي طريقة النجميع المحورة لصفة عدد السنابل بالنبات ، وكذلك في طريقة الانحدار من حبة واحدة لصفات عدد الأيام إلي طرد السنبلة وارتفاع النبات وعدد السنابل بالنبات ووزن الحبوب.

كما أوضحت النتائج أن جميع طرق التربية كانت مؤثرة في تحسين صفات ارتفاع النبات وعدد السنابل بالنبات وعدد الحبوب بالسنبلة ووزن الحبوب ، بينما كانت طريقتي تسجيل النسب والتجميع الدحورة مؤثرتين في تحسين صفة عدد الأيام إلي طرد النورة ووزن حبوب النبات.

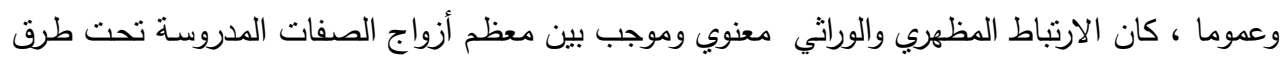

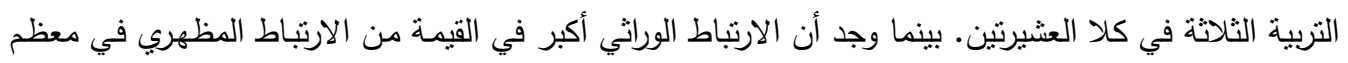
أزواج الصفات المدروسة تحت طرق التربية الثلاثة. 